Article

\title{
Pre-Emergence Herbicides and Mulches for Weed Control in Cutting Propagation
}

\author{
Anthony L. Witcher * and Isha Poudel \\ Department of Agricultural and Environmental Sciences, Tennessee State University, \\ Otis L. Floyd Nursery Research Center, McMinnville, TN 37110, USA; ipoudel@tnstate.edu \\ * Correspondence: awitcher@tnstate.edu; Tel.: +1-931-815-5147
}

Received: 30 July 2020; Accepted: 21 August 2020; Published: 25 August 2020

\begin{abstract}
Weed control is critical in cutting propagation to maximize root growth and liner quality, but hand weeding is time consuming and not cost efficient. Pre-emergence herbicides are widely used in container-grown nursery crop production, but concerns of potential phytotoxicity have limited widespread use in propagation. Mulches are a viable alternative for weed control but few products have been evaluated in propagation. Five pre-emergence herbicides and five mulches were evaluated for rooting stem cuttings of three nursery crop species and for control of four weed species. Mulches were applied $(0.8 \mathrm{~cm}$ depth) prior to sticking cuttings while pre-emergence herbicides were applied (low labeled rate) two weeks after sticking cuttings. Rooting percentage, root dry weight, and shoot dry weight were not affected by pre-emergence herbicide or mulch, except for butterfly bush (Buddleja davidii 'Nanho Blue') which was severely injured when treated with the pre-emergence herbicide isoxaben. Oxyfluorfen + oxadiazon provided excellent control of all tested weed species and has potential to be used in propagation of a number of crops. Mulches did not provide adequate weed control, but increased application depth may enhance efficacy and should be further evaluated.
\end{abstract}

Keywords: nursery crops; stem cuttings; herbicide efficacy

\section{Introduction}

Nursery crops are typically propagated in small-diameter containers (less than $10 \mathrm{~cm}$ ) and weeds have a negative impact on growth and liner quality. Weeds compete for water, nutrients, light, and space, thus any weed presence during propagation is detrimental due to the limited region for root development and close spacing of liners. Sanitation practices are most effective for preventing weed establishment and methods include using weed-free container substrate, maintaining the surrounding areas weed free, and removal of weeds prior to flowering [1,2]. Once weeds become established in or near the crop, a combination of manual and chemical (herbicide) methods must be used to successfully remove weeds and prevent further infestations.

Few herbicides are labeled for use in cutting propagation. Grass weeds can be easily controlled using a grass-selective post-emergence herbicide safe on most broadleaf crops. Unfortunately, actively-growing broadleaf weeds must be physically removed from containers due to the lack of broadleaf-selective post-emergence herbicides safe for over-the-top use in broadleaf nursery crop species [2-4]. Costs for manual weed control (hand weeding) can reach USD 9000 per hectare while an estimated overall economic loss of over USD 17,000 per hectare can be associated with weed infestations in nursery crops [3,4]. In recent years, nurseries have struggled to maintain an adequate labor force and labor shortages are likely to continue even though farm wages have increased [5]. As a result, growers must adopt less labor-intensive weed-management practices.

Pre-emergence herbicides are widely used for controlling weeds in nursery crop production, but no products are currently labeled for use on crops inside enclosed structures or during propagation. 
Many pre-emergence herbicides are in the dinitroaniline family and prevent weed development by disrupting cell mitosis in the root meristem [6]. Several dinitroaniline herbicides (oryzalin, pendimethalin, and trifluralin) have been evaluated in propagation, but significant root inhibition occurred to several crop species and these herbicides are not recommended for use $[7,8]$.

Alternatively, pre-emergence herbicides that are considered non root-inhibiting have potential for use in cutting propagation. Oxadiazon functions by inhibiting an enzyme active in chlorophyll synthesis, ultimately leading to cell degradation and thus does not directly affect root cell development. Several studies demonstrated oxadiazon was safe to apply during propagation of woody crop species, either prior to sticking cuttings or shortly afterward [7-9]. A granular formulation containing oxadiazon + oxyfluorfen was evaluated in two separate studies and found to have minimal to no impact on root development in cutting propagation $[9,10]$. Flumioxazin is in the same chemical family as oxadiazon and one research report noted flumioxazin was safely used in cutting propagation [10]. Isoxaben and indaziflam are in a chemical class with a mode of action which inhibits cellulose biosynthesis, but both are labeled for use in a wide range of nursery crops. Initial reports suggest isoxaben [9] and indaziflam [11] may have potential for use in propagation but future evaluations, as well as screening for species sensitivity, are needed.

Mulches are a non-chemical alternative to pre-emergence herbicides and have been thoroughly evaluated for weed control during crop production, but mulch use in propagation has not been widely reported. Rowe et al. [12] evaluated a pelletized wool product and found rooting was significantly inhibited when pellets were applied prior to rooting of cuttings. Certain mulch products may contain phytotoxic compounds and must be thoroughly evaluated prior to widespread use. Due to the small diameter containers used in propagation, only mulches with a small particle size and porous physical properties should be considered. Parboiled rice hulls are commercially available and are commonly used for weed control on container-grown crops inside greenhouses and on crop species sensitive to pre-emergence herbicides [13]. Altland and Krause [14] reported rice hulls applied at 1.3 to $2.5 \mathrm{~cm}$ depth provided nearly 100\% control of flexuous bittercress (Cardamine flexuosa) and had no effect on rose growth (Rosa 'Radrazz'). Pelletized recycled paper and compressed hardwood sawdust pellets can also provide effective weed control in containers, but reported research was conducted over 20 years ago $[15,16]$. Currently-available products of pelletized recycled paper and pelletized pine sawdust, sold for use as animal bedding, have not been evaluated for weed control but may be a viable weed control option for propagation.

Growers must take an integrated approach to weed control during propagation and emphasize sanitation and prevention. Identifying pre-emergence herbicides and mulches for use in propagation will provide growers with more options for managing weeds while increasing workforce efficiency and liner quality. Therefore, the objective of this research was to evaluate pre-emergence herbicides and mulches for safety on rooting cuttings and for efficacy against common nursery weeds.

\section{Materials and Methods}

\subsection{Stem Cutting Rooting and Development}

Two experiments (2018 and 2019) were conducted at the Tennessee State University Otis L. Floyd Nursery Research Center ( $35^{\circ} 42^{\prime} 22.4^{\prime \prime}$ N 85 $44^{\prime} 35.4^{\prime \prime}$ W) in McMinnville, TN (USDA Plant Hardiness Zone 7a). Both experiments included five pre-emergent herbicides, four mulches, and a non-treated control for a total of ten treatments in each experiment (Table 1). In 2018, semi-hardwood terminal stem cuttings (7.6-10 cm long) were collected from field-grown viburnum (Viburnum plicatum $f$. tomentosum 'Mariesii'). In 2019, softwood cuttings (three node, terminal, and sub-terminal) were collected from container-grown butterfly bush (Buddleja davidii 'Nanho Blue') and semi-hardwood terminal stem cuttings (7.6-10 cm long) were collected from field-grown viburnum and holly (Ilex cornuta 'Dwarf Burford'). All cuttings received a $3 \mathrm{~s}$ basal quick dip in rooting hormone at $500 \mathrm{ppm}$ indole-3-butyric acid (IBA) +250 ppm napthaleneacetic acid (NAA) for butterfly bush and viburnum or 2000 ppm IBA 
+1000 ppm NAA for holly (Dip'N Grow, Clackamas, OR, USA). A single cutting was inserted into individual $6.6 \mathrm{~cm}$ diameter square containers (SVD250, T.O. Plastics, Clearwater, MN, USA) filled with a $100 \%$ pine bark substrate amended (per $1 \mathrm{~m}^{3}$ ) with $3.6 \mathrm{~kg} 18 \mathrm{~N}-2.6 \mathrm{P}-6.6 \mathrm{~K}$ controlled-release fertilizer (18-6-8 Nutricote ${ }^{\circledR}$ Total Type 180; Florikan, Sarasota, FL, USA), 0.6 kg micronutrient granules (Micromax; ICL Specialty Fertilizers, Summerville, SC, USA), and $0.3 \mathrm{~kg}$ media surfactant granules (AquaGro 2000 G, Aquatrols, Paulsboro, NJ, USA).

Table 1. Product type, product name, pre-emergent herbicide active ingredient(s), application rate, and source for stem cutting rooting experiments and weed seed germination assays in 2018 and 2019.

\begin{tabular}{|c|c|c|c|c|c|}
\hline Year & Product Type & $\begin{array}{l}\text { Product/Trade } \\
\text { Name }\end{array}$ & $\begin{array}{c}\text { Common } \\
\text { Name/Description }\end{array}$ & Application Rate & Manufacturer \\
\hline 2018/2019 & Non-treated control & NA & NA & NA & NA \\
\hline $2018 / 2019$ & Herbicide & Gallery SC & Isoxaben & $599 \mathrm{~g}_{\text {ai ha }}{ }^{-1}$ & $\begin{array}{l}\text { Corteva Agriscience, } \\
\text { Indianapolis, IN }\end{array}$ \\
\hline $2018 / 2019$ & Herbicide & BroadStar & Flumioxazin & $420 \mathrm{~g}$ ai ha $^{-1}$ & $\begin{array}{l}\text { Valent U.S.A. Corp., } \\
\text { Walnut Creek, CA }\end{array}$ \\
\hline 2018/2019 & Herbicide & Marengo G & Indaziflam & $25 \mathrm{~g}_{\text {ai ha }}{ }^{-1}$ & $\begin{array}{l}\text { Bayer Environmental } \\
\text { Science, Cary, NC }\end{array}$ \\
\hline $2018 / 2019$ & Herbicide & Regal O-O & Oxyfluorfen + oxadiazon & $2240+1120 \mathrm{~g}$ ai ha $^{-1}$ & $\begin{array}{l}\text { Regal Chemical Company, } \\
\text { Alpharetta, GA }\end{array}$ \\
\hline $2018 / 2019$ & Herbicide & Ronstar G & Oxadiazon & $2240 \mathrm{~g}_{\text {ai ha }}{ }^{-1}$ & $\begin{array}{l}\text { Bayer Environmental } \\
\text { Science, Cary, NC }\end{array}$ \\
\hline $2018 / 2019$ & Mulch & Paper pellets & Pelletized recycled paper & $0.8 \mathrm{~cm}$ depth & MPP Inc., Wolcott, NY \\
\hline 2018/2019 & Mulch & Pine pellets & Pelletized pine sawdust & $0.8 \mathrm{~cm}$ depth & $\begin{array}{l}\text { Tractor Supply Company, } \\
\text { Brentwood, IN }\end{array}$ \\
\hline $2018 / 2019$ & Mulch & Vermiculite & \#2A coarse grade & $0.8 \mathrm{~cm}$ depth & $\begin{array}{c}\text { Thermo-O-Rock Inc., New } \\
\text { Eagle, PA }\end{array}$ \\
\hline 2018 & Mulch & Perlite & Coarse grade & $0.8 \mathrm{~cm}$ depth & $\begin{array}{l}\text { Whittemore Company Inc., } \\
\text { Lawrence, MA }\end{array}$ \\
\hline 2019 & Mulch & Rice hulls & Parboiled rice hulls & $0.8 \mathrm{~cm}$ depth & $\begin{array}{l}\text { Riceland Foods Inc., } \\
\text { Stuttgart, AR }\end{array}$ \\
\hline
\end{tabular}

Cuttings were collected and stuck (25 replicates per treatment) on 23 August 2018 and 6 June 2019. Mulches were applied $(0.8 \mathrm{~cm}$ final depth) to the substrate surface prior to sticking cuttings and herbicides were applied 2 weeks after sticking cuttings. Isoxaben was applied with a $\mathrm{CO}_{2}$ sprayer fitted with a flat spray nozzle (TP8003VS, TeeJet Technologies, Wheaton, IL, USA) and calibrated to deliver $280 \mathrm{~L} \mathrm{ha}^{-1}$ at $207 \mathrm{kpa}$. All other herbicides were applied using a handheld shaker. Containers were arranged in a completely randomized design (within species) and placed inside a shade structure (50\% shade cloth) under intermittent mist maintained at $12 \mathrm{~s}$ every $8 \mathrm{~min}$ from 6:00 am to 9:00 pm applied with mister nozzles (VibroNet with blue nozzle, Netafim USA, Fresno, CA, USA).

The experiments were terminated 10 weeks after sticking cuttings (WAS) in 2018 and 9 (butterfly bush and viburnum) or 15 (holly) WAS in 2019. Rooting percentage ( $\left.\%=\frac{\text { number of non-rooted cuttings }}{\text { number of rooted cuttings }} \times 100\right)$, root dry weight, and shoot dry weight (2019 only) were collected. Data from each species were analyzed separately with linear models for continuous responses and generalized linear models (binary distribution; logit link function) for binary responses using the GLIMMIX procedure of SAS (Version 9.3; SAS Institute, Inc., Cary, NC, USA) and differences between treatment means were determined using the Shaffer-Simulated method $(p<0.05)$.

\subsection{Weed Seed Germination Assays}

Weed seed germination assays were conducted and initiated on 11 September 2018 and 24 June 2019. Assays included five pre-emergent herbicides, four mulches, and a non-treated control (Table 1). Weed species included bittercress (Cardamine hirsuta), crabgrass (Digitaria sanguinalis), creeping woodsorrel (Oxalis corniculata), and mulberryweed (2019 only; Fatoua villosa). Square containers ( $9 \mathrm{~cm}$ diameter; SVD350, T.O. Plastics) were filled with a pine bark substrate and placed under intermittent mist (as previously 
described) and a separate set of containers was used for each species. Mulches and herbicides were applied and 20 (bittercress, creeping woodsorrel, mulberryweed) or 30 (crabgrass) seeds were surface sown in each container the following day.

In 2018, weeds were harvested and shoot fresh weight was recorded at 42 (bittercress and crabgrasss) or 56 (creeping woodsorrel) days after sowing (DAS). In 2019, germinated seeds (cotyledon stage or later) were counted at 14 and 28 DAS. Shoot fresh weight was recorded at 36 (crabgrass), 42 (bittercress and mulberryweed), or 63 (creeping woodsorrel) DAS. Data from each species were analyzed separately as previously described.

\section{Results}

\subsection{Stem Cutting Rooting and Development}

Rooting percentage was 95\% or greater for viburnum (2018 and 2019) and all treatments were similar to the non-treated control (Tables 2 and 3). Holly rooting percentage was $90 \%$ or greater and similar among all treatments and the non-treated control (Table 3). Butterfly bush rooting varied by treatment ranging $5 \%$ to $100 \%$ overall but rooting percentage was lowest for isoxaben (5\%) compared with all other treatments. Although reduced butterfly bush rooting percentage was observed for indaziflam $(70 \%)$ and oxadiazon $(80 \%)$, they were similar to the non-treated control.

Table 2. Rooting percentage and root dry weight of viburnum cuttings treated with pre-emergent herbicides or mulches in 2018.

\begin{tabular}{cccc}
\hline Treatment & Product Type & Rooting (\%) & Root Dry wt (g) \\
\hline Control & NA & $100 \mathrm{a}^{\mathrm{z}}$ & $0.51 \mathrm{ab}$ \\
Isoxaben & Herbicide & $100 \mathrm{a}$ & $0.37 \mathrm{~b}$ \\
Flumioxazin & Herbicide & $100 \mathrm{a}$ & $0.47 \mathrm{ab}$ \\
Indaziflam & Herbicide & $100 \mathrm{a}$ & $0.38 \mathrm{~b}$ \\
Oxyfluorfen + oxadiazon & Herbicide & $100 \mathrm{a}$ & $0.44 \mathrm{ab}$ \\
Oxadiazon & Herbicide & $100 \mathrm{a}$ & $0.59 \mathrm{a}$ \\
Perlite & Mulch ${ }^{\mathrm{x}}$ & $100 \mathrm{a}$ & $0.40 \mathrm{ab}$ \\
Vermiculite & Mulch & $95 \mathrm{a}$ & $0.48 \mathrm{ab}$ \\
Pine pellets & Mulch & $95 \mathrm{a}$ & $0.42 \mathrm{ab}$ \\
Paper pellets & Mulch & $100 \mathrm{a}$ & $0.51 \mathrm{ab}$ \\
\hline
\end{tabular}

z Means followed by different letters within columns indicate significant difference at $p<0.05$ using the Shaffer-Simulated method for multiple comparisons. ${ }^{y}$ Pre-emergent herbicides were applied at the low labeled rate two weeks after sticking cuttings. ${ }^{x}$ Mulches applied $(0.8 \mathrm{~cm}$ depth) prior to sticking cuttings.

Table 3. Rooting percentage of cuttings from three species treated with pre-emergent herbicides or mulches in 2019.

\begin{tabular}{ccccc}
\hline \multirow{2}{*}{ Treatment } & Product Type & Butterfly Bush & Holly & Viburnum \\
\cline { 3 - 5 } & & \multicolumn{3}{c}{ Rooting (\%) } \\
\hline Control & NA & $95 \mathrm{a} z$ & $100 \mathrm{a}$ & $95 \mathrm{a}$ \\
Isoxaben & Herbicide & $5 \mathrm{~b}$ & $100 \mathrm{a}$ & $100 \mathrm{a}$ \\
Flumioxazin & Herbicide & $100 \mathrm{a}$ & $100 \mathrm{a}$ & $100 \mathrm{a}$ \\
Indaziflam & Herbicide & $70 \mathrm{a}$ & $100 \mathrm{a}$ & $100 \mathrm{a}$ \\
Oxyfluorfen + oxadiazon & Herbicide & $90 \mathrm{a}$ & $90 \mathrm{a}$ & $100 \mathrm{a}$ \\
Oxadiazon & Herbicide & $80 \mathrm{a}$ & $100 \mathrm{a}$ & $95 \mathrm{a}$ \\
Rice hulls & Mulch & $95 \mathrm{a}$ & $100 \mathrm{a}$ & $95 \mathrm{a}$ \\
Vermiculite & Mulch & $95 \mathrm{a}$ & $95 \mathrm{a}$ & $100 \mathrm{a}$ \\
Pine pellets & Mulch & $85 \mathrm{a}$ & $100 \mathrm{a}$ & $100 \mathrm{a}$ \\
Paper pellets & Mulch & $100 \mathrm{a}$ & $100 \mathrm{a}$ & $100 \mathrm{a}$ \\
\hline
\end{tabular}

$\mathrm{z}$ Means followed by different letters within columns indicate significant difference at $p<0.05$ using the Shaffer-Simulated method for multiple comparisons. ${ }^{y}$ Pre-emergent herbicides were applied at the low labeled rate two weeks after sticking cuttings. ${ }^{x}$ Mulches applied $(0.8 \mathrm{~cm}$ depth) prior to sticking cuttings. 
In 2018, viburnum root dry weight was not significantly affected by pre-emergent herbicide or mulch and all treatments were similar compared to the non-treated control (Table 4). Similarly, in 2019 viburnum root dry weight was similar among all treatments. Although root dry weight was slightly reduced in isoxaben (28\%) and indaziflam (25\%) compared to the non-treated control in 2018, no such decrease was observed in 2019. For butterfly bush, root dry weight was lowest for isoxaben yet similar among the remaining treatments. Holly root dry weight was similar among all treatments and the non-treated control, but there was a numerical reduction in dry weight of over $25 \%$ for isoxaben, indaziflam, oxyfluorfen + oxadiazon, and paper pellets in comparison to the non-treated control.

Table 4. Root (RDW) and shoot (SDW) dry weight of cuttings from three species treated with pre-emergent herbicides or mulches in 2019.

\begin{tabular}{cccccccc}
\hline \multirow{2}{*}{ Treatment } & \multirow{2}{*}{ Product Type } & \multicolumn{2}{c}{ Butterfly Bush } & \multicolumn{2}{c}{ Holly } & \multicolumn{2}{c}{ Viburnum } \\
\cline { 3 - 7 } & & RDW (g) & SDW (g) & RDW (g) & SDW (g) & RDW (g) & SDW (g) \\
\hline Control & NA & $0.11 \mathrm{a}^{\mathrm{z}}$ & $0.75 \mathrm{~b}$ & $0.41 \mathrm{a}$ & $1.28 \mathrm{a}$ & $0.82 \mathrm{~b}$ & $1.59 \mathrm{~b}$ \\
Isoxaben & Herbicide & $0.00 \mathrm{~b}$ & $0.00 \mathrm{c}$ & $0.28 \mathrm{a}$ & $1.05 \mathrm{a}$ & $0.91 \mathrm{ab}$ & $1.98 \mathrm{ab}$ \\
Flumioxazin & Herbicide & $0.15 \mathrm{a}$ & $1.01 \mathrm{ab}$ & $0.36 \mathrm{a}$ & $1.44 \mathrm{a}$ & $0.72 \mathrm{~b}$ & $1.62 \mathrm{~b}$ \\
Indaziflam & Herbicide & $0.09 \mathrm{a}$ & $0.68 \mathrm{~b}$ & $0.31 \mathrm{a}$ & $1.20 \mathrm{a}$ & $0.85 \mathrm{~b}$ & $1.60 \mathrm{~b}$ \\
Oxyfluorfen + oxadiazon & Herbicide & $0.14 \mathrm{a}$ & $1.02 \mathrm{ab}$ & $0.30 \mathrm{a}$ & $1.17 \mathrm{a}$ & $1.04 \mathrm{ab}$ & $1.92 \mathrm{ab}$ \\
Oxadiazon & Herbicide & $0.15 \mathrm{a}$ & $1.09 \mathrm{ab}$ & $0.32 \mathrm{a}$ & $1.32 \mathrm{a}$ & $0.97 \mathrm{ab}$ & $1.85 \mathrm{ab}$ \\
Rice hulls & Mulch $\mathrm{x}$ & $0.18 \mathrm{a}$ & $1.60 \mathrm{a}$ & $0.37 \mathrm{a}$ & $1.42 \mathrm{a}$ & $1.24 \mathrm{a}$ & $2.10 \mathrm{ab}$ \\
Vermiculite & Mulch & $0.13 \mathrm{a}$ & $1.13 \mathrm{ab}$ & $0.33 \mathrm{a}$ & $1.43 \mathrm{a}$ & $1.19 \mathrm{a}$ & $2.31 \mathrm{a}$ \\
Pine pellets & Mulch & $0.10 \mathrm{a}$ & $0.70 \mathrm{~b}$ & $0.38 \mathrm{a}$ & $1.38 \mathrm{a}$ & $0.82 \mathrm{~b}$ & $1.76 \mathrm{ab}$ \\
Paper pellets & Mulch & $0.17 \mathrm{a}$ & $1.07 \mathrm{ab}$ & $0.30 \mathrm{a}$ & $1.35 \mathrm{a}$ & $1.01 \mathrm{ab}$ & $1.88 \mathrm{ab}$ \\
\hline
\end{tabular}

${ }^{z}$ Means followed by different letters within columns indicate significant difference at $p<0.05$ using the Shaffer-Simulated method for multiple comparisons. ${ }^{y}$ Pre-emergent herbicides were applied at the low labeled rate two weeks after sticking cuttings. ${ }^{x}$ Mulches applied $(0.8 \mathrm{~cm}$ depth) prior to sticking cuttings.

Shoot dry weight varied among treatments for butterfly bush but was lowest for isoxaben (Table 4). Rice hulls had the greatest shoot dry weight overall, 213\% greater than the non-treated control, while all remaining treatments were similar to the non-treated control. Viburnum shoot dry weight in vermiculite was $145 \%$ greater than the non-treated control, but was similar among all other treatments compared to the non-treated control. For holly, all treatments had similar shoot dry weight but this was $18 \%$ lower in isoxaben compared to the non-treated control.

\subsection{Weed Seed Germination Assays}

The number of germinated seeds tended to decrease slightly from 14 to 28 DAS for the herbicide and mulch treatments, thus only data for 28 DAS will be discussed. The average number of germinated seed for the non-treated controls was 2.1 (mulberryweed), 3.9 (creeping woodsorrel), 4.1 (crabgrass), and 15.5 (bittercress) (Table 5). Bittercress number was lowest for flumioxazin, isoxaben, oxyfluorfen + oxadiazon, and pine pellets. Indaziflam and oxyfluorfen + oxadiazon resulted in lower crabgrass number compared to the non-treated control. Mulberryweed number significantly decreased with isoxaben, flumioxazin, and oxyfluorfen + oxadiazon. The number of creeping woodsorrel was lower than the non-treated control for isoxaben, flumioxazin, oxyfluorfen + oxadiazon, and oxadiazon.

In 2018, isoxaben provided excellent control of bittercress with a $98 \%$ reduction in shoot fresh weight compared to the non-treated control (Table 6). Shoot fresh weight was also reduced by at least $60 \%$ in the remaining treatments compared to the non-treated control. In 2019, bittercress control was not as effective for several of the products as only isoxaben, oxyfluorfen + oxadiazon, and pine pellets reduced shoot fresh weight compared to the control (Table 7). Crabgrass had reduced shoot dry weight with indaziflam and oxyfluorfen + oxadiazon in both years, while flumioxazin and paper pellets were also effective in 2018. For creeping woodsorrel, reduced shoot fresh weight resulted for isoxaben, oxyfluorfen + oxadiazon, and paper pellets in 2018 while it was lower for all herbicides and the paper 
pellet mulch in 2019 when compared to the non-treated control. Mulberryweed growth was effectively controlled with isoxaben, flumioxazin, and oxyfluorfen + oxadiazon.

Table 5. Number of germinated seeds of four weed species at 14 and 28 days after sowing in containers treated with pre-emergent herbicides or mulches in 2019.

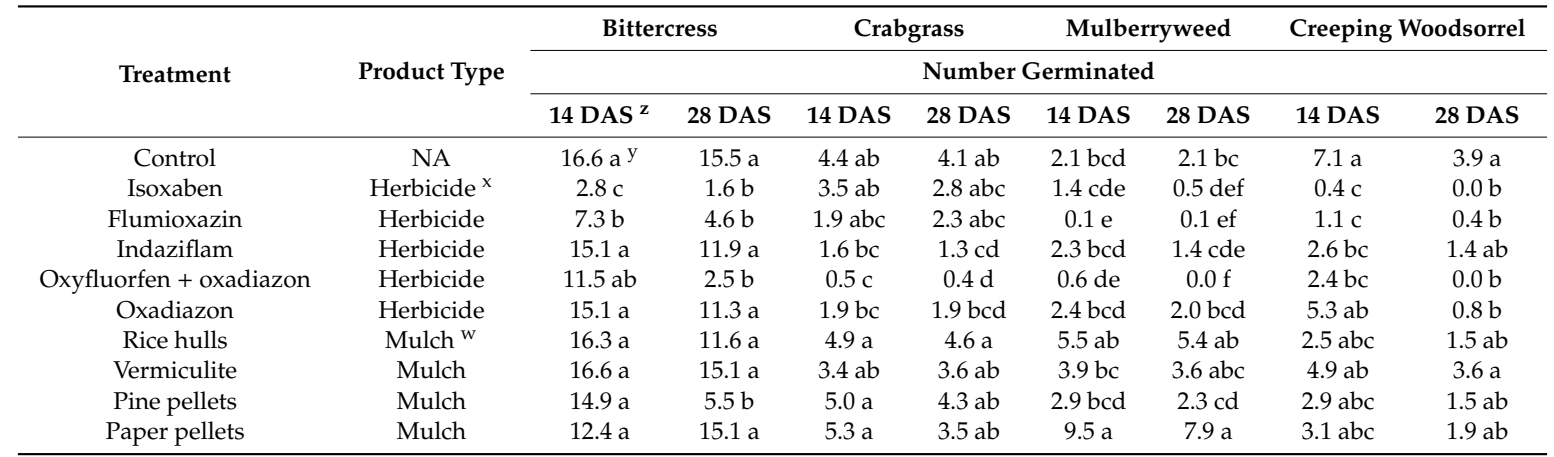

${ }^{\mathrm{z}}$ Days after sowing. ${ }^{\mathrm{y}}$ Means followed by different letters within columns indicate significant difference at $p<0.05$ using the Shaffer-Simulated method for multiple comparisons. ${ }^{\times}$Pre-emergent herbicides were applied at the low labeled rate. ${ }^{\mathrm{w}}$ Mulches applied at $0.8 \mathrm{~cm}$ depth.

Table 6. Shoot fresh weight of three weed species in containers treated with pre-emergent herbicides or mulches in 2018.

\begin{tabular}{ccccc}
\hline & & Bittercress & Crabgrass & Creeping Woodsorrel \\
\cline { 3 - 5 } Treatment & Product Type & \multicolumn{3}{c}{ Shoot Fresh wt (g) } \\
\cline { 3 - 5 } & NA & $2.48 \mathrm{a}^{\mathrm{z}}$ & $1.38 \mathrm{a}$ & $0.24 \mathrm{ab}$ \\
Control & Herbicide & $0.05 \mathrm{~d}$ & $0.84 \mathrm{abcd}$ & $0.04 \mathrm{c}$ \\
Isoxaben & Herbicide & $0.38 \mathrm{bcd}$ & $0.27 \mathrm{~d}$ & $0.10 \mathrm{bc}$ \\
Indamioxazin & Herbicide & $0.72 \mathrm{~b}$ & $0.36 \mathrm{~cd}$ & $0.15 \mathrm{abc}$ \\
Oxyfluorfen + oxadiazon & Herbicide & $0.76 \mathrm{~b}$ & $0.38 \mathrm{~cd}$ & $0.05 \mathrm{c}$ \\
Oxadiazon & Herbicide & $0.90 \mathrm{~b}$ & $0.87 \mathrm{abcd}$ & $0.10 \mathrm{bc}$ \\
Perlite & Mulch $\mathrm{b}$ & $0.95 \mathrm{~b}$ & $1.28 \mathrm{ab}$ & $0.10 \mathrm{bc}$ \\
Vermiculite & Mulch & $0.79 \mathrm{~b}$ & $1.49 \mathrm{a}$ & $0.31 \mathrm{a}$ \\
Pine pellets & Mulch & $0.61 \mathrm{bc}$ & $1.01 \mathrm{abc}$ & $0.08 \mathrm{bc}$ \\
Paper pellets & Mulch & $0.14 \mathrm{~cd}$ & $0.49 \mathrm{bcd}$ & $0.03 \mathrm{c}$ \\
\hline
\end{tabular}

${ }^{\mathrm{z}}$ Means followed by different letters within columns indicate significant difference at $p<0.05$ using the Shaffer-Simulated method for multiple comparisons. y Pre-emergent herbicides were applied at the low labeled rate.

${ }^{x}$ Mulches applied at $0.8 \mathrm{~cm}$ depth.

Table 7. Shoot fresh weight of four weed species in containers treated with pre-emergent herbicides or mulches in 2019.

\begin{tabular}{cccccc}
\hline \multirow{2}{*}{ Treatment } & Product Type & Bittercress & Crabgrass & Mulberryweed & Creeping Woodsorrel \\
\cline { 3 - 5 } & & & & Shoot Fresh wt (g) \\
\hline Control & NA & $2.1 \mathrm{a}^{\mathrm{z}}$ & $2.8 \mathrm{a}$ & $2.1 \mathrm{ab}$ & $1.6 \mathrm{ab}$ \\
Isoxaben & Herbicide & $0.4 \mathrm{~cd}$ & $1.5 \mathrm{ab}$ & $0.2 \mathrm{~cd}$ & $0.0 \mathrm{c}$ \\
Flumioxazin & Herbicide & $1.5 \mathrm{abc}$ & $1.2 \mathrm{abc}$ & $0.3 \mathrm{~cd}$ & $0.1 \mathrm{c}$ \\
Indaziflam & Herbicide & $1.8 \mathrm{a}$ & $0.7 \mathrm{bc}$ & $1.1 \mathrm{bc}$ & $0.3 \mathrm{c}$ \\
Oxyfluorfen + oxadiazon & Herbicide & $0.2 \mathrm{~cd}$ & $0.1 \mathrm{c}$ & $0.0 \mathrm{~d}$ & $0.0 \mathrm{c}$ \\
Oxadiazon & Herbicide & $2.3 \mathrm{a}$ & $1.3 \mathrm{abc}$ & $1.1 \mathrm{abc}$ & $0.0 \mathrm{c}$ \\
Rice hulls & Mulch & $2.5 \mathrm{a}$ & $3.2 \mathrm{a}$ & $2.9 \mathrm{a}$ & $2.1 \mathrm{ab}$ \\
Vermiculite & Mulch & $2.1 \mathrm{a}$ & $2.9 \mathrm{a}$ & $1.9 \mathrm{ab}$ & $2.6 \mathrm{a}$ \\
Pine pellets & Mulch & $0.6 \mathrm{bcd}$ & $1.2 \mathrm{abc}$ & $0.6 \mathrm{bcd}$ & $0.8 \mathrm{bc}$ \\
Paper pellets & Mulch & $1.4 \mathrm{ab}$ & $2.3 \mathrm{ab}$ & $1.4 \mathrm{ab}$ & $0.3 \mathrm{c}$ \\
\hline
\end{tabular}

${ }^{\mathrm{z}}$ Means followed by different letters within columns indicate significant difference at $p<0.05$ using the Shaffer-Simulated method for multiple comparisons. ${ }^{y}$ Pre-emergent herbicides were applied at the low- labeled rate. ${ }^{\mathrm{X}}$ Mulches applied at $0.8 \mathrm{~cm}$ depth. 


\section{Discussion}

All pre-emergence herbicides and mulches evaluated in our study were safely used in stem cutting propagation of three nursery crop species, with the exception of isoxaben on butterfly bush. Only $5 \%$ of the butterfly bush cuttings rooted for isoxaben while all other treatments had $70 \%$ or greater rooting. Limited research has been reported for using isoxaben (Gallery) in propagation. Cochran et al. [9] reported mixed results when isoxaben was applied before sticking cuttings of loropetalum (Loropetalum chinense 'Ruby') where suppressed root growth occurred in only one of the two experiments. In a study with container-grown butterfly bush, Polomski et al. [17] reported injury from a sprayable formulation of isoxaben (Gallery $75 \mathrm{WP}$ ) but no injury to plants treated with a granular formulation containing isoxaben (Snapshot $2.5 \mathrm{TG}$ ). Gallery SC is a sprayable formulation of isoxaben, thus the foliar application 2 WAS cuttings in the present study may have caused damaged to leaf tissue thus negatively affecting rooting. Gallery SC is labeled for over-the-top application on many crop species (including holly, loropetalum, and viburnum) and may be safe for use in propagation of some labeled crops yet individual species should be evaluated for safety.

Oxyfluorfen + oxadiazon and oxadiazon are considered non root-inhibiting herbicides and have been previously demonstrated as safe for use during cutting propagation. Thetford and Gilliam [8] reported no differences in rooting percentage or root rating for cuttings (Ilex $\times$ attenuate 'Fosteri, Abelia $\times$ grandiflora 'Sherwoodii', Buxus microphylla var. koreana, and Ilex crenata 'Compacta') when oxadiazon was applied prior to sticking. Davies and Duray [18] found that oxadiazon was also safe for propagation when applied after sticking cuttings of several crop species (Hibiscus rosa-sinensis 'White Leprechaun', Ilex cornuta 'Burfordii', Lantana camara 'New Gold', and Trachelospermum asiaticum). Oxyfluorfen + oxadiazon and oxadiazon applied at or 5 WAS cuttings did not injure roots (Rhododendron 'Girard Rose', Ilex crenata 'Hetzii', and Ilex crenata 'Compacta') based on visual ratings [10]. In a more recent study, Cochran et al. [9] reported no differences in root growth (Loropetalum chinense 'Ruby') between oxyfluorfen + oxadiazon or oxadiazon and the non-treated control when applied at or 6 WAS cuttings but the authors did note suppressed root growth from the same treatments in a prior experiment.

Most previous research using pre-emergence herbicides during propagation was conducted prior to the introduction of flumioxazin or indaziflam, thus limited information is available for these products in propagation. Cook and Neal [10] reported flumioxazin performed similarly to oxadiazon and oxyfluorfen + oxadiazon, with no effect on root quality of cuttings when applied at sticking which was similar to the present study. A study by Marble and Chandler [11] indicated that rooting response varied by crop species for cuttings treated with indaziflam at sticking and all crop species showed a numerical reduction in root growth. In the present study, flumioxazin and indaziflam demonstrated potential for use during propagation but further research on application timing and species sensitivity should be conducted. In propagation, application of pre-emergence herbicides prior to sticking cuttings would be less labor intensive and more efficient compared to applications after sticking which could hinder uniform application especially for granular products.

Although several pre-emergence herbicides have been found safe and effective to use during cutting propagation, these products have several limitations. Firstly, there are no pre-emergence herbicides currently labeled for use on crops inside an enclosed structure such as a greenhouse or overwintering house. Fortunately, many nurseries propagate woody ornamental crops under a naturally-ventilated shade structure during the growing season which reduces the risk of phytotoxicity from herbicide volatility. Secondly, cuttings are typically rooted in small-diameter containers and the label for some pre-emergence herbicides limit the size of container to which the product can be applied. Growers interested in using pre-emergence herbicides during propagation should consider these factors, test small groups of individual species/cultivars to assess any potential injury prior to widespread use, and also understand any subsequent crop injury is the sole liability of the herbicide applicator.

Mulches may be a viable method of weed control for propagating in enclosed structures, for use on herbicide sensitive crop species, or for growers that want to avoid the risk of herbicide injury. All the mulches evaluated in the current study were safely used during propagation, with no adverse effects 
on rooting. Nevertheless, weed control efficacy was overall inferior for the mulches when compared with the pre-emergent herbicides. Isoxaben and oxyfluorfen + oxadiazon provided excellent control of bittercress in both years, yet only pine pellet mulch inhibited bittercress growth in both years. None of the mulches provided control of crabgrass, while indaziflam and oxyfluorfen + oxadiazon provided excellent crabgrass control. For creeping woodsorrel, paper pellet was the only mulch that provided adequate control while several of the herbicides were effective, including oxyfluorfen + oxadiazon.

Mulches can be effective for controlling weeds in containers, but they are most effective when applied to a depth of at least $2.5 \mathrm{~cm}[19,20]$. In the present study, the mulch depth $(0.8 \mathrm{~cm})$ was selected due to the small container size and unknown effects to crop rooting. The thin mulch layer was likely inadequate to effectively prevent weed seed germination or suppress weed growth. Additionally, the intermittent mist used to maintain a high moisture environment for propagation may have contributed to reduced efficacy providing weed seeds with ample moisture for germination and development. Altland et al. [13] reported parboiled rice hulls applied at 1.3 and $2.5 \mathrm{~cm}$ depths in nursery containers inhibited germination and establishment of flexuous bittercress (Cardamine flexuosa) and creeping woodsorrel. Pelletized recycled waste paper has also been evaluated as a mulch in nursery containers and when applied at a $2.5 \mathrm{~cm}$ depth provided excellent control of prostrate spurge (Chamaesyce maculata) [16]. Similarly, compressed hardwood sawdust pellets reportedly reduced weed number by $85 \%$ in nursery containers [15]. The pine pellet used in the present study expanded to twice the volume after exposure to irrigation and created a solid barrier on the surface that physically prevented many weeds from establishing roots. Ongoing research by the authors has focused on the effects of increased mulch depths on rooting and weed control efficacy.

Ultimately, proper sanitation and exclusion of weed seed dispersal into the propagation area is the best method of weed control but is still not $100 \%$ effective. Manually removing weeds requires significant time and labor resources that must be redirected from other important nursery tasks. Adopting methods for preventing or reducing weed seed germination during propagation would lower overall costs for growers, increase productivity of available personnel, and increase the quality and marketability of the liners. Oxyfluorfen + oxadiazon is a viable option for propagation of certain crop species due to lack of crop injury and broad spectrum weed control. Other pre-emergence herbicides have potential for use during propagation but crop species sensitivity may limit widespread use and should be further evaluated. Mulches are a viable alternative to pre-emergence herbicides in propagation especially in enclosed structures, but additional screening is needed to determine crop safety at increased mulch depths.

Author Contributions: Conceptualization and methodology, A.L.W.; data collection and formal analysis, A.L.W. and I.P.; writing—original draft preparation, review and editing, A.L.W.; funding acquisition, A.L.W. All authors have read and agreed to the published version of the manuscript.

Funding: This research was supported by the National Institute of Food and Agriculture (NIFA), United States Department of Agriculture (USDA) Evans-Allen grant under award number TENX-1925-CCOCP and the Center for Applied Nursery Research.

Acknowledgments: The authors are grateful to Terry Kirby for assistance with data collection and project maintenance.

Conflicts of Interest: The authors declare no conflict of interest.

\section{References}

1. Altland, J. Weed Control in Container Crops: A Guide to Effective Weed Management Through Preventative Measures; Oregon State University Extension Service: Corvallis, OR, USA, 2003; p. 8823.

2. Neal, J.C. Weed control in woody liner production. Proc. Intl. Plant Prop. Soc. 2000, 50, 528-531.

3. Case, L.T.; Mathers, H.M.; Senesac, A.F. A review of weed control practices in container nurseries. HortTechnology 2005, 15, 535-545. [CrossRef]

4. Judge, C.A.; Neal, J.C.; Weber, J.B. Dose and concentration responses of common nursery weeds to Gallery, Surflan and Treflan. J. Environ. Hort. 2004, 22, 106-112.

5. Charlton, D.; Taylor, J.E. A declining farm workforce: Analysis of panel data from rural Mexico. Am. J. Agric. Econ. 2016, 1-23. [CrossRef] 
6. Weed Science Society of America. Summary of Herbicide Mechanism of Action According to the Weed Science Society of America. Available online: http://wssa.net/wp-content/uploads/WSSA-Mechanism-of-Action.pdf (accessed on 20 July 2020).

7. Gilliam, C.H.; Eakes, D.J.; Olive, J.W. Herbicide use during propagation affects root initiation and development. J. Environ. Hort. 1993, 11, 157-159.

8. Thetford, M.; Gilliam, C.H. Herbicide use in propagation: Effects on rooting and root growth of stem cuttings. J. Environ. Hort. 1991, 9, 21-23.

9. Cochran, D.R.; Gilliam, C.H.; Eakes, D.J.; Wehtje, G.R.; Knight, P.R. Herbicide use in propagation of Loropetalum chinense 'Ruby'. J. Environ. Hort. 2008, 26, 139-143.

10. Cook, J.C.; Neal, J.C. Effects of herbicides and application timing on rooting of azalea and Japanese holly cuttings. Proc. South. Nurs. Res. Conf. 2001, 46, 422-424.

11. Marble, C.; Chandler, A. Determining Safety of Preemergence Herbicide Use during Propagation of Three Woody Ornamental Species. Available online: http://www.canr.org/newsletter/PreemergenceHerbicideinPro pagation.pdf (accessed on 20 July 2020).

12. Rowe, B.; Fernandez, T.; Cregg, B. Effect of wool pellet mulch on propagation, crop growth, and weed control in liners. Propag. Ornam. Plants 2004, 4, 29-36.

13. Altland, J.E.; Boldt, J.K.; Krause, C.C. Rice hull mulch affects germination of bittercress and creeping woodsorrel in container plant culture. Am. J. Plant Sci. 2016, 7, 2359-2375. [CrossRef]

14. Altland, J.; Krause, C. Parboiled rice hull mulch in containers reduces liverwort and flexuous bittercress growth. J. Environ. Hort. 2014, 32, 59-631.

15. Barnes, H.W. Use of compressed hardwood sawdust pellets as a weed control mechanism for container plants. Proc. Int. Plant Prop. Soc. 1999, 49, 389-390.

16. Smith, D.R.; Gilliam, C.H.; Edwards, J.H.; Olive, J.W.; Eakes, D.J.; Williams, J.D. Recycled waste paper as a non-chemical alternative for weed control in container production. J. Environ. Hort. 1998, 16, 69-75.

17. Polomski, R.F.; Whitwell, T.; Tucker, K. Tolerance of Buddleia davidii 'Charming Summer' to preemergence herbicides. Proc. South. Nurs. Res. Conf. 1995, 40, 294-296.

18. Davies, F.T.; Duray, S.A. Effect of preemergent herbicide application on rooting and subsequent liner growth of selected nursery crops. J. Environ. Hort. 1992, 10, 181-186.

19. Cochran, D.R.; Gilliam, C.H.; Eakes, D.J.; Wehtje, G.R.; Knight, P.R.; Olive, J. Mulch depth affects weed germination. J. Environ. Hort. 2009, 27, 85-90.

20. Saha, D.; Marble, S.C.; Pearson, B.J.; Perez, H.E.; MacDonald, G.E.; Odero, D.C. Mulch type and depth, herbicide formulation, and postapplication irrigation volume influence on control of common landscape weed species. HortTechnology 2019, 29, 65-77. [CrossRef] 